\title{
THE EFFECT OF EXERCISE ON THE CONCENTRATION AND TURNOVER OF PLASMA NONESTERIFIED FATTY ACIDS *
}

\author{
By S. J. FRIEDBERG, $\dagger$ W. R. HARLAN, JR., D. L. TROUT aNd E. H. ESTES, JR. \\ (From the Central Reference Laboratory and Radioisotopes Unit, Veterans Administration Hos- \\ pital, Durham, N. C., and Department of Medicine, Duke University Medical Center, \\ Durham, N. C.)
}

(Submitted for publication June 22, 1959; accepted September 18, 1959)

Recent work has suggested that the albuminbound fatty acids of blood (herein called FFA, the free or nonesterified fatty acids of blood) (1) might be oxidized directly by muscle. If this is so, and if this material is utilized promptly, either directly or through an intermediate, acute changes would be expected to take place in blood during increased physical activity. Such behavior would be particularly expected because fatty acids are known to turn over rapidly and to circulate in low concentration. Therefore a study was undertaken to investigate changes in plasma fatty acid during exercise and to evaluate the direction and magnitude of these changes.

Few human experiments on this subject have been published and little information is available about fatty acid utilization by skeletal muscle. Andres, Cader and Zierler (2) noted that the amount of glucose taken up by the human forearm is less than equivalent to the local oxygen consumption and $\mathrm{CO}_{2}$ production. Furthermore, their measurements of forearm R.Q. hinted at relatively extensive consumption of lipids or lipid products. Gordon has shown that the human forearm usually (but not always) takes up more fatty acid than it releases, suggesting that these fatty acids are taken up directly by muscle cells (3). Interpretation of this type of measurement with respect to direct utilization of a substrate is difficult since net arteriovenous differences reflect the sum of a number of possible effects such as deposition into fat depots, release from fat depots

* This investigation was supported in part by a research grant from the Life Insurance Medical Research Fund, in part by Research Grant H-1217 (C6) from the National Heart Institute, United States Public Health Service, and in part by the Regional Center for the Study of Aging, Duke University.

$\dagger$ Research Fellow, American Heart Association. and uptake by muscle. The in vitro utilization of fatty acid by skeletal muscle at rest and during electrical stimulation has recently been demonstrated by Fritz and co-workers who have, in addition, shown inhibition of the reaction with increasing concentration of albumin in the medium $(4,5)$.

The work of Fredrickson and Gordon, and Bierman and colleagues $(6,7)$ on the disappearance from the vascular compartment of injected carboxyl-labeled, albumin-bound fatty acid is pertinent to the present discussion since similar techniques have been applied in the present investigation.

\section{METHODS}

The study was carried out in two parts: first, the effect of exercise on arterial plasma FFA level; and second, the effect of exercise on the disappearance of injected, prepared albumin-bound radiopalmitate.

It was found that lactic acid generated during exercise caused considerable spurious elevation of FFA as determined by the Dole method (1). For this reason a modified Dole procedure was used, consisting of washing the organic solvent layer with 0.02 per cent sulfuric acid. ${ }^{1}$ The method and its validation will be described in detail elsewhere (8).

Triglycerides were determined by the method of Van Handel and Zilversmit (9), glucose by the iodometric titration of Somogyi (10), and lactic acid by the method of Barker and Summerson (11). Plasma lipolytic ac-

1 In the organic solvent phase of the Dole procedure 1.5 to 2.5 per cent of lactic acid of plasma equilibrates. This means that every milligram per $100 \mathrm{ml}$. increase in lactic acid of plasma would be expected to increase the apparent FFA titration by about $2 \mu$ Moles per L. This theoretical increase correlates well with actual differences in "washed" and "unwashed" FFA titrations in exercising individuals and with values simultaneously obtained by the Gordon and Cherkes method. The modified procedure was found to yield 91 per cent recovery of fatty acid. 
tivity was determined by an adaptation of a method by Engelberg (12-14). This adaptation measures the release of fatty acid from Ediol (a fat emulsion) incubated with plasma.

Measurement of the activity of plasma after injection of radiopalmitate was carried out in the following manner. Two ml. samples of plasma were extracted as in the Dole procedure for determination of FFA. Eight $\mathrm{ml}$. aliquots from the organic solvent phase, which represent the fatty acids from $1.78 \mathrm{ml}$. plasma, were placed in separate tubes. In order to separate fatty acids from neutral lipid ${ }^{2}$ (15), $8 \mathrm{ml}$. of $0.1 \mathrm{~N} \mathrm{NaOH}$ in 50 per cent ethanol was added to the tubes to convert the fatty acids to the sodium salt and extract them into an aqueous phase. After removal of the upper phase containing neutral fats, the sodium palmitate in the aqueous layer was acidified to a pink end point by addition of $0.25 \mathrm{~N} \mathrm{HCl}$ using thymol blue indicator. The fatty acids were then re-extracted with heptane and the heptane layer was transferred to $50 \mathrm{ml}$. beakers. This was accomplished by removing as much hepatane as possible and then washing twice with more heptane and transferring the residue. After partial evaporation of heptane, the remaining heptane and fatty acid were transferred quantitatively to deep stainless steel planchets, $2.5 \mathrm{~cm}$. in diameter. Ninety-nine per cent isopropyl alcohol was used for final washing and quantitative transfer from the beakers to the planchets. The fatty acids were dried under a stream of cool air at room temperature and counted as soon as possible in a windowless gas flow counter. With the amount of residual material on the planchets, self-absorption was considered negligible. Planchets were stored in a freezer to minimize sublimation. After several days of storage, no detectable loss of activity was noted, probably because of the presence of sufficient endogenous fatty acid. When subjected to the above procedure, 88.5 per cent of palmitic acid-1- $C^{14}$ added to plasma was recovered. Duplicate extractions showed a maximum variation of 1.6 per cent from the mean.

Albumin-bound palmitic acid-1-C $\mathrm{C}^{14}$ was prepared by dissolving the acid in methyl ethyl ketone and converting to the potassium salt by means of a slight excess of alcoholic potassium hydroxide. Three $\mathrm{ml}$. of physiologic saline was added and the solution was evaporated over a water bath until the odors of alcohol and methyl ethyl ketone were no longer detectable. Equivalent quantities of human albumin were added and the clear solution was sterilized by passage through an ultrafine bacterial filter.

In handling the data concerning disappearance of radiopalmitate, the following assumptions were made: first, during the period of exercise considered in this study, there is no consistent or significant change in plasma FFA concentration following the initial fall

2 Data by Fredrickson and Gordon (6), confirmed in this laboratory, indicate that there is considerable conversion of FFA to neutral fats and that the latter must be removed for accurate determination of palmitic acid$1-C^{14}$ activity.
TABLE I

Arterial FFA concentrations in millimoles per liter obtained at first and tenth minutes after injection of radiopalmitate during rest and exercise

\begin{tabular}{lccccc}
\hline & \multicolumn{2}{c}{ Rest } & & \multicolumn{2}{c}{ Exercise } \\
\cline { 2 - 3 } \cline { 5 - 6 } Subject & $\begin{array}{c}\text { First } \\
\text { min. }\end{array}$ & $\begin{array}{c}\text { Tenth } \\
\text { min. }\end{array}$ & & $\begin{array}{c}\text { First } \\
\text { min. }\end{array}$ & $\begin{array}{c}\text { Tenth } \\
\text { min. }\end{array}$ \\
\hline CK & 0.67 & 0.66 & & 0.56 & 0.43 \\
MJ & 0.76 & 0.96 & & 0.60 & 0.54 \\
RB & 1.07 & 1.16 & & 0.77 & 0.83 \\
RW & 1.24 & 1.18 & & 0.79 & 0.97 \\
RP & 0.42 & 0.33 & & 0.31 & 0.33 \\
WF & 0.69 & 0.60 & & 0.54 & 0.60 \\
\hline
\end{tabular}

(Table I) ; second, the initial part of the curve representing the semilogarithmic plot of the disappearance of radiopalmitate lies sufficiently close to a straight line during both rest and exercise to permit useful estimates of FFA transfer rates based on equations describing such straight line relationships; third, in the steady state and with constant transfer rates for the unlabeled substance, the observable behavior of a tracer is independent of the reaction order (16-18) and the transfer equation has the form of an equation describing a first order reaction (19). The departure from linearity could be the result of a number of possible factors such as recirculation of label (6) or differences in the rate of release of FFA from various binding sites on albumin (20). Although a rise in plasma FFA concentration could account for the apparent decrease in the rate of radiopalmitate disappearance, this is not the case here, since a decrease always occurred regardless of whether FFA concentration rose, fell, or remained the same either during rest or after the initial fall caused by exercise.

Assuming constancy of flux of unlabeled FFA into and out of plasma: $d x=-x F / W$ dt where $x$ equals the amount of label in plasma; $t$, the time in minutes; $W$, the amount of unlabeled fatty acid in plasma; and $F$, the number of millimoles of fatty acid entering or leaving the vascular compartment per minute. Then, $x=x_{0} e^{-r t / w}$. Since $F / W$ is constant and equals the fraction of the total fatty acid in the vascular compartment leaving per minute, let $\mathrm{F} / \mathrm{W}=\mathrm{K}$. Then, $\mathrm{x}=\mathrm{x}_{0} \mathrm{e}^{-\mathrm{zt}}(19,21)$.

The slope of the disappearance curve for radiopalmitate from the second to the fourth minute after injection was used to establish the value " $\mathrm{K}$," as in the studies of Fredrickson and Gordon (6). This was done because the region usually represents the first clear straight line after an interval of time in which mixing in the blood is reasonably certain to be complete. Though this is generally true of curves obtained in resting subjects, there is reservation concerning the validity of this choice where exercise curves are concerned, so " $\mathrm{K}$ " was also calculated from the one to two minute slope. These reservations will be discussed at a later point. A FFA concentration obtained one minute after injection of label was used to estimate total plasma FFA, W, in the calculation of flux, assuming a plasma volume of $3.5 \mathrm{~L}$. 
TABLE II

The effect of exercise on plasma FFA concentration*

\begin{tabular}{|c|c|c|c|c|c|c|c|c|}
\hline & M. R. & B. L. & E. B. & J. O. & G. M. & P. B. & G. W. & Mean \\
\hline $\begin{array}{l}\text { First control } \\
\text { Second control } \\
\text { After } 7 \mathrm{~min} \text {. exercise } \\
\text { After } 15 \mathrm{~min} \text {. exercise } \\
\text { After } 15 \mathrm{~min} \text {. rest }\end{array}$ & $\begin{array}{l}0.72 \\
0.75 \\
0.66 \\
0.69 \\
0.98\end{array}$ & $\begin{array}{l}1.12 \\
1.06 \\
0.76 \\
0.96 \\
1.20\end{array}$ & $\begin{array}{l}0.75 \\
0.74 \\
0.51 \\
0.48 \\
0.94\end{array}$ & $\begin{array}{l}0.96 \\
0.97 \\
0.78 \\
0.68 \\
1.04\end{array}$ & $\begin{array}{l}0.61 \\
0.75 \\
0.47 \\
0.45 \\
0.99\end{array}$ & $\begin{array}{l}1.08 \\
1.12 \\
0.72 \\
0.71 \\
1.29\end{array}$ & $\begin{array}{l}0.69 \\
0.73 \\
0.53 \\
0.52 \\
0.69\end{array}$ & $\begin{array}{l}0.85 \\
0.87 \\
0.63 \\
0.64 \\
1.02\end{array}$ \\
\hline
\end{tabular}

* FFA concentration is expressed in millimoles per liter.

\section{EXPERIMENTAL}

First experiment. Seven healthy male volunteers between the ages of 20 and 25 were selected. These subjects were permitted a 600 calorie, low fat, high carbohydrate breakfast and were then fasted for six hours before and throughout the procedure. A Cournand needle was positioned in a brachial artery in each subject. After a 15 minute rest period, subjects exercised vigorously for 15 minutes by pedaling a stationary bicycle. The subjects were instructed to exercise as vigorously as possible, but to pace themselves so that they would be able to continue for 12 to 15 minutes. Blood samples were drawn in heparinized syringes during all phases of the procedure for determination of blood fatty acid, glucose, triglyceride, lactic acid and lipoprotein lipase activity.

Second experiment. Another group of eight healthy male volunteers between the ages of 21 and 25 was given $0.002 \mathrm{mc}$. of prepared albumin-bound palmitic acid-1- $\mathrm{C}^{14}$ intravenously while in the resting state, and brachial artery blood samples were drawn every minute for 10 minutes.

From 30 to 35 minutes after the resting samples were obtained the subjects began vigorously pedaling a stationary bicycle. After two to three minutes of exercise, another $0.002 \mathrm{mc}$. of palmitic acid-1-C $\mathrm{C}^{14}$ was given and the sampling repeated as in the control period, but with the subjects maintaining vigorous activity.

Plasma samples were analyzed for FFA concentration and, in addition, were extracted as previously outlined for measurement of palmitic acid-1-C $\mathrm{C}^{\mathbf{1 4}}$ activity. Semilogarithmic plots of plasma palmitic acid-1- $\mathrm{C}^{\mathbf{1 4}}$ activity were used to measure the disappearance rate of the radioisotope from the vascular compartment.

\section{RESULTS}

\section{The effect of exercise on blood FFA level}

The results (Table II) reveal consistent, fairly large and rapid falls in the level of arterial FFA during exercise. These effects are best demonstrated graphically (Figure 1). The average control level of $0.87 \mathrm{mMole}$ per L. fell to $0.64 \mathrm{mMole}$ per L. during exercise, a drop of 26.4 per cent $(p<0.01)$. After a 15 minute rest period, the

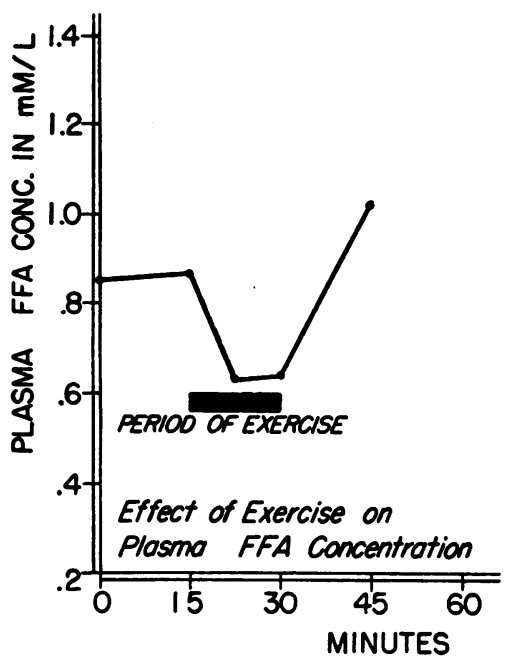

Fig. 1. The Effect of Exercise on Plasma fFa Concentration

average level rose to $1.02 \mathrm{mMoles}$ per L., a level significantly greater than the control values. No significant changes related to exercise were noted in blood glucose, triglyceride or serum lipoprotein lipase activity. Blood lactic acid was elevated considerably during exercise, rising from 10.9 to $68.9 \mathrm{mg}$. per $100 \mathrm{ml}$. and from 7.2 to $67 \mathrm{mg}$. per $100 \mathrm{ml}$. in the two subjects in whom measurements were made. Furthermore, during the short period of exercise studied, the lowered FFA levels remained stabilized (Table I) until the physical activity was stopped, after which fatty acid concentration rose to levels above those of the control period $(\mathrm{p}<0.01)$.

\section{Effect of exercise on the disappearance of palmitic acid-1-C ${ }^{14}$ from blood}

In the eight subjects studied, the initial rate of disappearance of $0.002 \mathrm{mc}$. of palmitic acid-1- $\mathrm{C}^{14}$ was more rapid during exercise than at rest. This can be seen by inspection of the graph of mean 


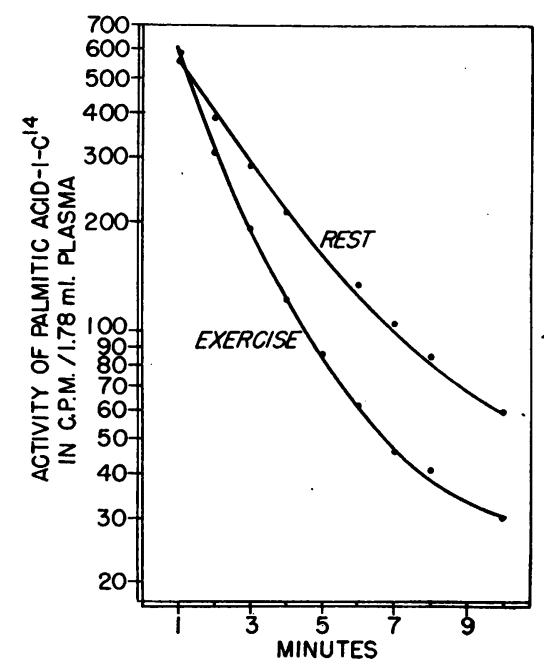

Fig. 2. Disappearance from Plasma of Palmitic Acid-1-C ${ }^{14}$ at Rest and During Exercise

The curves are drawn from mean values from eight subjects.

values (Figure 2), in which the logarithms of the concentrations in counts per minute are plotted against time. The values obtained during the second and fourth minutes of the resting and exercise curve were used to calculate the constant
" $\mathrm{K}$ " (Table III), representing the fractional rate of disappearance of FFA per minute, i.e., the fraction of the amount of FFA present in the blood disappearing per minute (6) (vide supra). During the second to fourth minutes, the mean value for " $K$ " was 0.294 per minute at rest and 0.473 per minute during exercise, an increase of 61 per cent. This would mean that the mean half-life of plasma FFA during the specified time changed from 2.36 to 1.46 minutes.

\section{DISCUSSION}

The data indicate that the amount of exercise performed promptly lowered plasma FFA levels. This lowering was rapid, and maximum in the first specimen drawn at seven to eight minutes after exercise was begun. In addition, an equally rapid rise above the pre-exercise level occurred upon cessation of exercise.

The above data show that exercise lowers FFA, but do not reveal whether this is due to an accelerated removal from or a decreased entry into the vascular compartment. This problem is resolved by the second part of the study which shows that exogenous palmitic acid-1-C $\mathrm{C}^{\mathbf{1 4}}$ is re-

TABLE III

Calculated flux, calculated fractional disappearance rates of plasma FFA during rest and exercise, and data used for calculations

\begin{tabular}{|c|c|c|c|c|c|c|c|c|c|}
\hline Subject & & $\begin{array}{c}\mathrm{cpm} \text { at } \\
1 \mathrm{~min} .\end{array}$ & $\begin{array}{l}\mathrm{cpm} \text { at } \\
2 \mathrm{~min} .\end{array}$ & $\underset{4 \mathrm{~min}}{\mathrm{cpm} \text { at }}$ & $\begin{array}{l}\text { FFA conc. } \\
\text { at } 1 \text { min. } \\
\text { in } \mathrm{mM} . / \mathrm{L} .\end{array}$ & $\underset{2-4}{K}$ min. & $\begin{array}{l}2-4 \text { min. } \\
\text { Flux/L. } \\
\text { plasma }\end{array}$ & $\underset{1-2 \mathrm{~min}}{\mathrm{~K}}$ & $\begin{array}{c}1-2 \text { min. } \\
\text { Flux/L. } \\
\text { plasma }\end{array}$ \\
\hline M. J. & $\begin{array}{l}\text { Rest } \\
\text { Ex. }\end{array}$ & $\begin{array}{l}703 \\
799\end{array}$ & $\begin{array}{l}443 \\
409\end{array}$ & $\begin{array}{l}240 \\
167\end{array}$ & $\begin{array}{l}0.76 \\
0.60\end{array}$ & $\begin{array}{l}0.307 \\
0.437\end{array}$ & $\begin{array}{l}0.23 \\
0.26\end{array}$ & $\begin{array}{l}0.460 \\
0.668\end{array}$ & $\begin{array}{l}0.35 \\
0.40\end{array}$ \\
\hline R. B. & $\begin{array}{l}\text { Rest } \\
\text { Ex. }\end{array}$ & $\begin{array}{l}448 \\
577\end{array}$ & $\begin{array}{l}335 \\
291\end{array}$ & $\begin{array}{l}200 \\
105\end{array}$ & $\begin{array}{l}1.07 \\
0.77\end{array}$ & $\begin{array}{l}0.256 \\
0.512\end{array}$ & $\begin{array}{l}0.28 \\
0.39\end{array}$ & $\begin{array}{l}0.290 \\
0.687\end{array}$ & $\begin{array}{l}0.31 \\
0.53\end{array}$ \\
\hline R. P. & $\begin{array}{l}\text { Rest } \\
\text { Ex. }\end{array}$ & $\begin{array}{l}661 \\
516\end{array}$ & $\begin{array}{l}356 \\
193\end{array}$ & $\begin{array}{r}166 \\
68\end{array}$ & $\begin{array}{l}0.36 \\
0.31\end{array}$ & $\begin{array}{l}0.382 \\
0.522\end{array}$ & $\begin{array}{l}0.14 \\
0.16\end{array}$ & $\begin{array}{l}0.619 \\
0.987\end{array}$ & $\begin{array}{l}0.22 \\
0.31\end{array}$ \\
\hline R. W. & $\begin{array}{l}\text { Rest } \\
\text { Ex. }\end{array}$ & $\begin{array}{l}445 \\
439\end{array}$ & $\begin{array}{l}386 \\
223\end{array}$ & $\begin{array}{r}223 \\
82\end{array}$ & $\begin{array}{l}1.24 \\
0.84\end{array}$ & $\begin{array}{l}0.274 \\
0.500\end{array}$ & $\begin{array}{l}0.34 \\
042\end{array}$ & $\begin{array}{l}0.143 \\
0.677\end{array}$ & $\begin{array}{l}0.18 \\
0.52\end{array}$ \\
\hline C. $\mathbf{K}$. & $\begin{array}{l}\text { Rest } \\
\text { Ex. }\end{array}$ & $\begin{array}{l}510 \\
448\end{array}$ & $\begin{array}{l}318 \\
265\end{array}$ & $\begin{array}{l}187 \\
110\end{array}$ & $\begin{array}{l}0.67 \\
0.50\end{array}$ & $\begin{array}{l}0.266 \\
0.444\end{array}$ & $\begin{array}{l}0.18 \\
0.22\end{array}$ & $\begin{array}{l}0.472 \\
0.525\end{array}$ & $\begin{array}{l}0.32 \\
0.26\end{array}$ \\
\hline J. R. & $\begin{array}{l}\text { Rest } \\
\text { Ex. }\end{array}$ & $\begin{array}{l}561 \\
690\end{array}$ & $\begin{array}{l}430 \\
423\end{array}$ & $\begin{array}{l}235 \\
180\end{array}$ & & $\begin{array}{l}0.302 \\
0.427\end{array}$ & & $\begin{array}{l}0.265 \\
0.488\end{array}$ & \\
\hline L. S. & $\begin{array}{l}\text { Rest } \\
\text { Ex. }\end{array}$ & $\begin{array}{l}492 \\
550\end{array}$ & $\begin{array}{l}365 \\
332\end{array}$ & $\begin{array}{l}243 \\
145\end{array}$ & & $\begin{array}{l}0.203 \\
0.414\end{array}$ & & $\begin{array}{l}0.299 \\
0.504\end{array}$ & \\
\hline W. F. & $\begin{array}{l}\text { Rest } \\
\text { Ex. }\end{array}$ & $\begin{array}{l}634 \\
669\end{array}$ & $\begin{array}{l}467 \\
342\end{array}$ & $\begin{array}{l}228 \\
117\end{array}$ & $\begin{array}{l}0.69 \\
0.56\end{array}$ & $\begin{array}{l}0.358 \\
0.536\end{array}$ & $\begin{array}{l}0.25 \\
0.30\end{array}$ & $\begin{array}{l}0.306 \\
0.670\end{array}$ & $\begin{array}{l}0.21 \\
0.38\end{array}$ \\
\hline Mean & $\begin{array}{l}\text { Rest } \\
\text { Ex. }\end{array}$ & $\begin{array}{l}\mathbf{5 5 7} \\
587\end{array}$ & $\begin{array}{l}388 \\
310\end{array}$ & $\begin{array}{l}276 \\
192\end{array}$ & & $\begin{array}{l}0.294 \\
0.473\end{array}$ & $\begin{array}{l}0.248 \\
0.301\end{array}$ & $\begin{array}{l}0.356 \\
0.650\end{array}$ & $\begin{array}{l}0.265 \\
0.398\end{array}$ \\
\hline
\end{tabular}


moved more rapidly during exercise. Since Fredrickson and Gordon have pointed out that the removal of labeled palmitic acid is qualitatively identical with the removal of most other long chain fatty acids, it is concluded that the early effect of exercise is to lower plasma FFA by accelerating its removal from blood.

Flux, or the amount of FFA entering and leaving the vascular compartment per minute, as calculated from the two to four minute values of " $\mathrm{K}$," was $0.175 \mathrm{mMole}$ per minute higher during exercise, an increase of 25 per cent $(\mathrm{p}<$ $0.02)$.

Inspection of the mean exercise and resting curves (Figure 2) shows that the rate of disappearance of label during exercise is more rapid during Minutes one to two than subsequently. If one assumes that mixing is complete at one minute and uses the one to two minute values for calculation of " $\mathrm{K}$," the " $\mathrm{K}$ ' $\mathrm{s}$ " for rest and exercise then become 0.356 and 0.650 per minute, respectively, a difference of 82 per cent $(p<0.01)$; and since plasma FFA is unchanged, the calculated differences in flux would be greater than those calculated above ( 45 per cent). Since the earliest values after mixing is complete are more likely to represent the true disappearance rate of label from plasma, there is some virtue in choosing these points instead of the two and four minute points as others have done in such calculations (6). Lack of knowledge of the time of complete mixing makes it impossible to choose the proper portions of the curves with certainty, ${ }^{3}$ nevertheless, regardless of the choice, an increase in flux both into and out of plasma exists.

The rise in plasma FFA after exercise is of interest and could mean that " $K$ " suddenly returns to a lower level while mobilization factors are still operating at an accelerated rate.

Fredrickson and Gordon (6) have shown that " $\mathrm{K}$ " varies inversely with plasma fatty acid concentration in the resting individual at levels below 0.6 to $0.8 \mathrm{mMole}$ FFA per L. The resting

${ }^{3}$ Experiments with Evans blue dye indicate that mixing is complete between 90 to 120 seconds (22). However, only minor fluctuations in concentration occur after 30 seconds. It is felt, in relation to the present investigation, that there is more error in the first minute samples but that this error is not great at rest and that it is smaller during exercise.

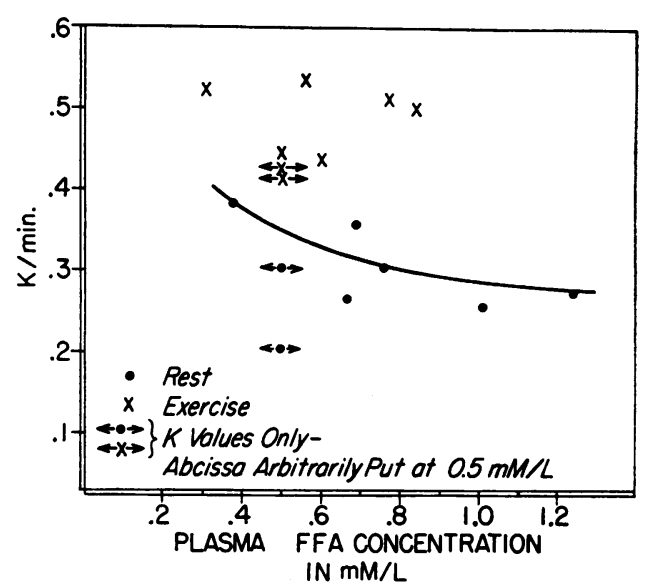

Fig. 3. The Relationship of Plasma FFA ConCentration to the Fractional Disappearance Rate at Rest and During Exercise

data as seen in Figure 3 are consistent with this observation, but the changes in " $\mathrm{K}$ " brought about by exercise are outside this range and cannot be accounted for merely on the basis of the decrease in FFA concentration.

The possible effect of lactic acid production during exercise on the level of plasma FFA is raised by the above data. Since increased blood concentration of this substrate persists for much longer than the decrease in plasma fatty acid (23) it is felt that there is probably no immediate relationship between the two and that elevated lactic acid is not responsible for the decline in plasma FFA concentration. In a single experiment, infusion of sodium lactate had no effect on plasma FFA.

The data presented do not determine the fate of the removed FFA. However, unpublished studies by Fredrickson (24) show a five- to sixfold increase in $\mathrm{C}^{14} \mathrm{O}_{2}$ excretion during exercise. This and similar problems in FFA utilization in relation to exercise are being examined currently in our laboratory.

\section{SUMMARY AND CONCLUSIONS}

1. The relationship between exercise and plasma fatty acid turnover was studied by observing the rate of disappearance of palmitic acid-1-C ${ }^{14}$ and by studying changes in plasma FFA concentration.

2. Acute exercise lowers plasma FFA concentration. There is a significant rise in plasma FFA concentration immediately after exercise. 
3. Exercise accelerates the disappearance of administered albumin-bound radiopalmitate and increases the fractional disappearance rate of FFA.

4. Flux of plasma FFA is greater during exercise than during rest.

\section{ACKNOWLEDGMENT}

The authors wish to thank Drs. Henry Kamin and Ronald C. Greene for their invaluable advice and suggestions in these studies. The technical assistance of Miss Helen L. Hilderman, Mrs. Mary Ruth Greenfield, Mrs. Nancy C. Johnson and Mrs. Sue H. Peters is gratefully acknowledged.

\section{REFERENCES}

1. Dole, V. P. A relation between non-esterified fatty acids in plasma and the metabolism of glucose. J. clin. Invest. 1956, 35, 150.

2. Andres, R., Cader, G., and Zierler, K. L. The quantitatively minor role of carbohydrate in oxidative metabolism by skeletal muscle in intact man in the basal state. Measurements of oxygen and glucose uptake and carbon dioxide and lactate production in the forearm. J. clin. Invest. 1956, 35, 671.

3. Gordon, R. S., Jr. Unesterified fatty acid in human blood plasma. II. The transport function of unesterified fatty acid. J. clin. Invest. 1957, 36, 810.

4. Fritz, I. B., Davis, D. G., Holtrop, R. H., and Dundee, H. Fatty acid oxidation by skeletal muscle during rest and activity. Amer. J. Physiol. 1958, 194, 379.

5. Fritz, I. B., and McEwen, B. Effects of Carnitine on fatty acid oxidation by muscle. Science 1959, 129, 334.

6. Fredrickson, D. S., and Gordon, R. S., Jr. The metabolism of albumin-bound $\mathrm{C}^{\mathbf{1 4}}$-labeled unesterified fatty acids in normal human subjects. J. clin. Invest. 1958, 37, 1504.

7. Bierman, E. L., Schwartz, I. L., and Dole, V. P. Action of insulin on release of fatty acids from tissue stores. Amer. J. Physiol. 1957, 191, 359.

8. Trout, D. L. Titration of non-esterified fatty acids. In preparation.

9. Van Handel, E., and Zilversmit, D. B. Micromethod for the direct determination of serum triglycerides. J. Lab. clin. Med. 1957, 50, 152.
10. Somogyi, M. Notes on sugar determination. J. biol. Chem. 1952, 195, 19.

11. Barker, S. B., and Summerson, W. H. The colorimetric determination of lactic acid in biological material. J. biol. Chem. 1941, 138, 535.

12. Engelberg, H. Human endogenous lipemia clearing activity. Studies of lypolysis and effects of inhibitors. J. biol. Chem. 1956, 222, 601.

13. Engelberg, $H$. In vitro studies of human plasma lipolytic activity before and after oral fat intake. J. appl. Physiol. 1957, 11, 155.

14. Engelberg, H. In vitro studies of the lipolysis of postalimentary lipemia in man. Metabolism 1958, 7, 172.

15. Borgström, B. Investigation on lipid separation methods. Separation of phospholipids from neutral fat and fatty acids. Acta physiol. scand. 1952, 25, 101.

16. Reiner, J. M. Study of metabolic turnover rates by means of isotopic tracers. I. Fundamental relations. Arch. Biochem. 1953, 46, 53.

17. Reiner, J. M. Study of metabolic turnover rates by means of isotopic tracers. II. Turnover in a simple reaction system. Arch. Biochem. 1953, 46, 80.

18. Raker, J. W., Taylor, I. M., Weller, J. M., and Hastings, A. B. Rate of potassium exchange of human erythrocyte. J. gen. Physiol. 1950, 33, 691.

19. Robertson, J. S. Theory and use of tracers in determining transfer rates in biological systems. Physiol. Rev. 1957, 37, 133.

20. Goodman, D. S. The interaction of human serum albumin with long-chain fatty acid anions. J. Amer. chem. Soc. 1958, 80, 3892.

21. Zilversmit, D. B., Entenman, C., and Fishler, M. C. On calculation of 'turnover time' and 'turnover rate' from experiments involving the use of labeling agents. J. gen. Physiol. 1943, 26, 325.

22. Nicholson, J. W., III, Burchell, H. B., and Wood, E. H. A method for the continuous recording of Evans blue dye curves in arterial blood, and its application to the diagnosis of cardiovascular abnormalities. J. Lab. clin. Med. 1951, 37, 353.

23. Tepperman, J., and Tepperman, H. M. On the blood lactic acid response to measured exercise in hypoxic human subjects. J. clin. Invest. 1948, 27, 176.

24. Fredrickson, D. S. Personal communication. 